\title{
The Preparation and Properties of Lysophosphatidylserine
}

\author{
By L. RATHBONE, W. L. MAGEE ANd R. H. S. THOMPSON \\ Department of Chemical Pathology, Guy's Hospital Medical School, London, S.E. 1
}

(Received 13 November 1961)

\begin{abstract}
Although lysolecithin has been frequently prepared and has been the subject of much research, other lysophosphatides have not been studied in detail. Our interest in nervous tissue led us to use human brain as the starting material from which phosphatidylserine-rich fractions were prepared by the method of Folch (1942). Long \& Penny (1957) demonstrated that the phosphatidylserine-containing fraction of ox brain was slowly attacked by the venom of the cottonmouth moccasin in an ethereal solution in the presence of $\mathrm{Ca}^{2+}$ ions. In the present work, however, phosphatidylserine was readily converted into lysophosphatidylserine by cottonmouth-moccasin venom in the $2,4,6$-collidine-ether system described by Magee \& Thompson (1960).
\end{abstract}

\section{EXPERIMENTAL}

\section{Materials}

Chemicals. Chloroform and methanol (analytical reagents from Hopkin and Williams Ltd.) were distilled through a fractionating column before use. Chloroform was stabilized by the addition of methanol to a final concentration of $2 \%(\mathrm{v} / \mathrm{v})$. Silicic acid was a product of the Mallinckrodt Chemical Co. Ltd., and Hyflo Super-Cel was from Hopkin and Williams Ltd.

Snake venom. The dried venom of the cottonmouth moccasin, Agkistrodon piscivorus piscivorus, was obtained from the Ross Allen's Reptile Institute, Silver Springs, Florida, U.S.A.

Buffer. 2,4,6-Collidine buffer (0.05 $\mathrm{M}, \mathrm{pH} 6.75)$ was made up as described by Dawson \& Elliott (1959). The $\mathrm{pH}$ was finally adjusted with the use of a glass electrode.

\section{Methods}

Preparation of fraction III from brain. A phosphatidylserine-rich fraction (fraction III) was prepared from postmortem human brain according to Folch (1942). Yields varied from 1.5 to $3.2 \mathrm{~g} . / \mathrm{kg}$. wet wt. of tissue.

Preparation of acid-washed fraction III. The procedure was based on that of Folch, Lees \& Sloane-Stanley (1957) modified as follows. Fraction III was dissolved in [chloroform-methanol $(2: 1, v / v)]$-water $(19: 1, v / v)$ to give a final concentration of about $5 \mathrm{mg}$. $/ \mathrm{ml}$. Hydrochloric acid $(0.2 \mathrm{vol}$. of $0.1 \mathrm{~N})$ was added to the solution in a stoppered cylinder, and the phases were mixed by inversion five times. After centrifuging, the upper phase was removed and discarded. Chloroform-methanol-water $(3: 48: 47$, by vol.) was added to the lower phase in amounts equivalent to about 0.2 vol. of the original lipid solution. After mixing and centrifuging, the upper phase was discarded. Inter- facial fluff was not removed. Washing with the chloroformmethanol-water ( $3: 48: 47$, by vol.) was repeated twice, and finally methanol was added to the lower phase to bring the remnants of upper phase into solution.

Chromatography. This was carried out on columns of silicic acid essentially as described by Hanahan, Dittmer \& Warashina (1957). In the present work, except where otherwise stated, $70 \mathrm{~g}$. of silicic acid was mixed with $35 \mathrm{~g}$. of Hyflo Super-Cel by shaking in a stoppered bottle. Chloroform-methanol $(4: 1, v / v)$ was added and the resulting slurry filtered on a Büchner funnel. The adsorbent was resuspended in chloroform-methanol $(4: 1, v / v)$ and the washing procedure repeated three times. The washed adsorbent was finally suspended in chloroform-methanol $(4: 1, v / v)$ and poured into a tube $2.5 \mathrm{~cm}$. in diameter closed at one end by a small plug of cotton wool overlaid by glass wool. Lipids were applied in a solution of chloroformmethanol $(4: 1, v / v)$ containing approx. $3 \mathrm{mg}$. of phosphorus $/ \mathrm{ml}$. The column loading was $0.45-1.32 \mathrm{mg}$. of phosphorus/g. of silicic acid. Elution was carried out successively with chloroform-methanol mixtures (4:1, 3:2 and $1: 4, \nabla / v)$, solvent changes being made as shown in Fig. 1.

Phosphorus estimations. These were carried out by the method of Taussky \& Shorr (1953) or by the method of Berenblum \& Chain (1938) as modified by Bartley (1953).

Serine and ethanolamine estimations. These were carried out as described by Magee, Baker \& Thompson (1960) or by the method of Axelrod, Reichenthal \& Brodie (1953).

Fatty acid estimations. Samples containing approx. $5 \mu$ moles of fatty acid were placed in stoppered tubes and the solvent was removed. Sodium hydroxide $(2 \mathrm{ml}$. of $2 \mathrm{~N}$ ) was then added and hydrolysis allowed to proceed at $38^{\circ}$ with shaking for $2 \mathrm{hr}$. A drop of saturated aq. cresol red was then added and the solution made just acid by the addition of $\mathrm{HCl}$. Ether (3 ml.) was added and the mixture shaken for $30 \mathrm{sec}$. The ether layer was transferred to a $25 \mathrm{ml}$. round-bottomed flask and the extraction repeated twice. The solvent was removed in vacuo and the flasks were set aside overnight in an evacuated desiccator containing $\mathrm{KOH}$. The fatty acids were quantitatively transferred to stoppered tubes by extracting the residues three times with $2 \mathrm{ml}$. portions of acetone, filtering each extract through Whatman no. 1 filter paper $(2 \mathrm{~cm}$. diam.) and evaporating to dryness. The residue was finally dissolved in $3 \mathrm{ml}$. of acetone-thanol $(1: 1, v / v), 2$ drops of aq. cresol red were added and the acids were titrated with $0.02 \mathrm{~N}-\mathrm{NaOH}$ in $90 \%(\mathrm{v} / \mathrm{v})$ methanol from a horizontal Conway burette. The solution was stirred with a stream of nitrogen. Blanks and standards of palmitic acid were treated similarly to the samples.

Estimations of acyl ester linkages. These were carried out as described by Stern \& Shapiro (1953) with a standard of pure ovolecithin. 
Identification of fatty acids. The fatty acids prepared by hydrolysis were converted into their methyl esters by interaction with diazomethane as described by Baker (1961). Subsequent gas chromatography was carried out at $176^{\circ}$ with, as the stationary phase, a mixture of diethyleneglycol adipate polyester (LAC-IR-296) (obtained from Cambridge Industries Ltd., Cambridge, Mass., U.S.A.) and acid-washed commercial Celite 545 (85-100 mesh) in the proportion of $1: 3$ by weight. Argon was used as the mobile phase at a flow rate of $34 \mathrm{ml} . / \mathrm{min}$.

Reaction of phosphatide with venom. The reaction medium used was that described by Magee \& Thompson (1960) for ovolecithin. Phosphatide preparations were emulsified in $0 \cdot 05 \mathrm{M}-2,4,6$-collidine buffer, $\mathrm{pH} 6 \cdot 75$, to give a final concentration of approx. $0.12 \mathrm{mg}$. of phosphorus (about $3 \mathrm{mg}$. of lipid)/ml. Diethyl ether $(0.1$ vol. $)$ was then added. Venom dissolved in $5 \mathrm{~mm}-\mathrm{CaCl}_{2}$ was added to the phosphatide emulsion to give final concentrations of $0.21 \mathrm{mg}$. of venom $/ \mathrm{ml}$. and $0.2 \mathrm{mM}-\mathrm{CaCl}_{2}$. After mixing, the reaction was allowed to proceed at room temperature over- night. Chloroform-methanol $(2: 1, v / v)(4$ vol.) was then added, the mixture was shaken vigorously and the phases were allowed to separate in the cold room. The upper phase and as much of the interfacial protein as possible was removed and discarded.

Final procedure for the preparation of lysophosphatidylserine: Stage 1. Acid-washed fraction III was prepared as described above from up to $3 \mathrm{~g}$. of fraction III. The final solution was evaporated to dryness at $35^{\circ}$ in a rotary evaporator, small quantities of chloroform-methanol (2:1, $\nabla / v)$ being added at the end to ensure removal of water. Stage 2. The dried lipid from stage 1 was dissolved in chloroform-methanol $(4: 1, v / v)$ to give a concentration of 3.0-3.5 mg. of phosphorus $/ \mathrm{ml}$., and the solution was filtered through a sintered-glass filter (porosity 3). The filtrate was transferred to a column of silicic acid-Hyflo Super-Cel and elution carried out as described above [see Fig. $1(c)$ ]. The eluted fractions corresponding to the first peak and containing about $90 \%$ of the applied phospholipid were pooled, and the solvent was removed at $35^{\circ}$.
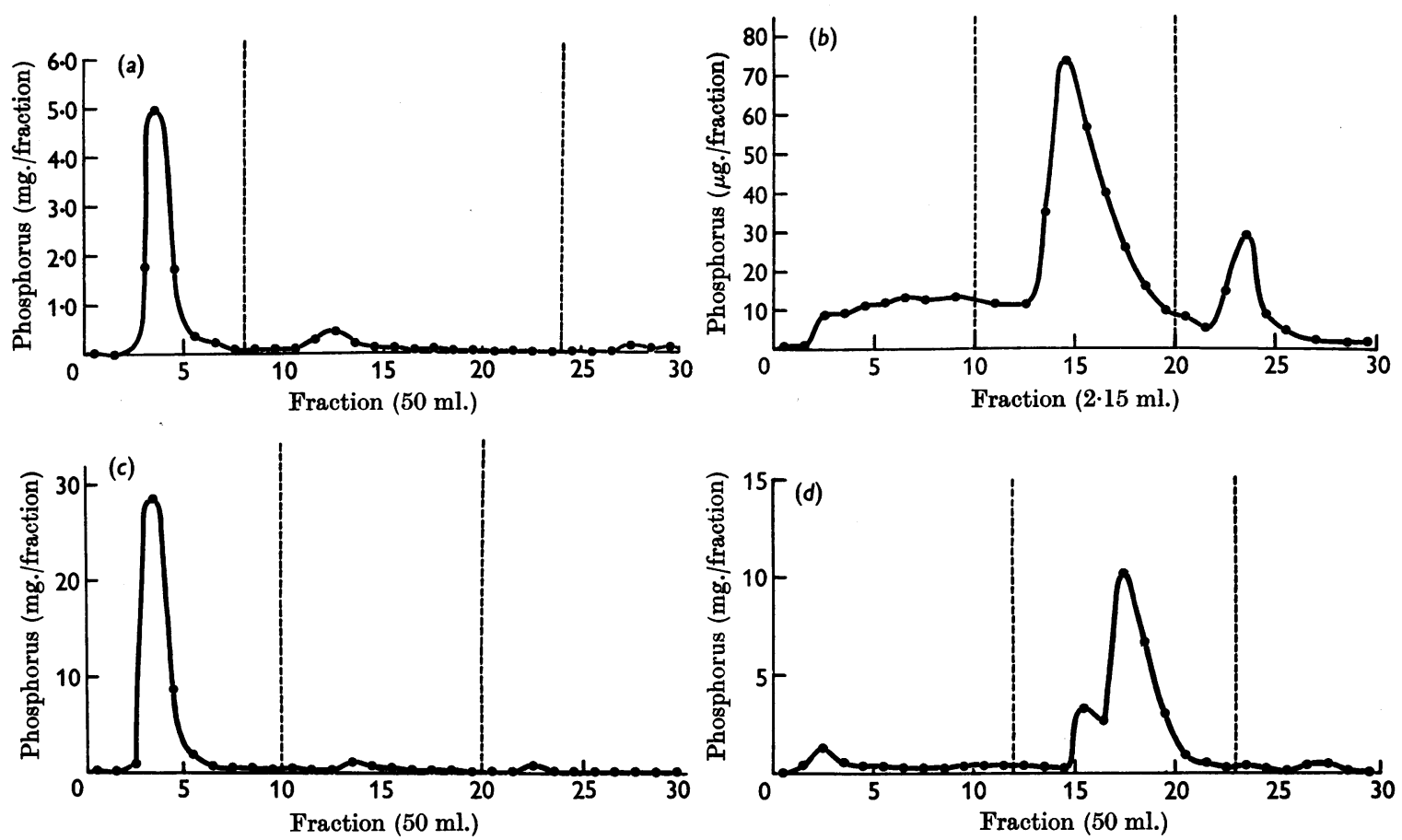

Fig. 1. Chromatographic behaviour of untreated and acid-washed fraction III and lysophosphatidylserine. The fractions on the left of each diagram were eluted with chloroform-methanol $(4: 1, \mathrm{v} / \mathrm{v})$; those in the middle with chloroform-methanol $(3: 2, v / v)$; and those on the right with chloroform-methanol $(1: 4, v / v)$. (a) Chromatography of fraction III containing approx. $15 \mathrm{mg}$. of phosphorus on a silicic acid-Hyflo Super-Cel column containing $40 \mathrm{~g}$. of silicic acid. (b) Chromatography of a different preparation of fraction III containing $0.48 \mathrm{mg}$. of phosphorus on a similar column containing $2.2 \mathrm{~g}$. of silicic acid. (c) Chromatography of the preparation of fraction III used in $(b)$ which had been washed with hydrochloric acid. Lipid containing 53 mg. of phosphorus was chromatographed on a silicic acid-Hyflo Super-Col column containing $70 \mathrm{~g}$. of silicic acid. Lipid eluted with chloroform-methanol $(4: 1, v / v)$ (peak 1) was used as the substrate for the venom in preparation 1. (d) Chromatography of the chloroform-methanol extract of the 2,4,6-collidine-ether medium containing first-peak substances (c) after reaction with venom. Lipid containing $32 \mathrm{mg}$. of phosphorus was chromatographed on a silicic acid-Hyflo Super-Cel column identical with that used in (c). Fractions 17-23 inclusive were pooled and analysed for lysophosphatidylserine (Table 1, preparation 1). 
Stage 3. 2,4,6-Collidine buffer, pH 6.75 $(0.05 \mathrm{M})$, was added to the flask containing the dried lipid which was then emulsified by vigorous shaking. Ether, venom and $\mathrm{CaCl}_{2}$ were then added in the proportions stated above. After the reaction had proceeded overnight at room temperature the lipids were extracted with chloroform-methanol $(2: 1, v / v)$ as described above and the extract was evaporated to dryness.

Stage 4. The residue from stage 3 was dissolved in chloroform-methanol $(4: 1, \nabla / v)$ to give a final concentration of 3.0-3.5 mg. of phosphorus $/ \mathrm{ml}$. and the solution was filtered through a sintered-glass filter (porosity 3). The darkreddish-brown filtrate was transferred to a second silicic acid-Hyflo Super-Cel column, identical with the first, and elution carried out in the same way [see Fig. $1(d)$ ]. After the elution of material giving a small initial peak the solvent was changed to chloroform-methanol $(3: 2, \mathrm{v} / \mathrm{v})$, whereupon over $80 \%$ of the applied lipid phosphorus was eluted. The portion of the elution curve obtained with this solvent exhibited a small peak, the eluted fractions corresponding to this being brown in colour. This was closely followed, and partly overlapped, by a larger peak corresponding to the bulk of the lipid [Fig. $1(d)$ ]. The smaller peak was visible only as a shoulder on the larger peak in the elution curve obtained with more heavily loaded columns. The fractions corresponding to the larger peak were pooled, the solvent was removed and the residue was dissolved in chloroform to give a light-amber solution containing approx. $1 \mathrm{mg}$. of phosphorus $/ \mathrm{ml}$. Analytical data for two consecutive preparations are given in Table 1. The molar ratios for fatty acid, serine, acyl ester linkage and phosphorus were very similar in the two preparations, and the absolute phosphorus content of the purer preparation agreed well with the theoretical value for lysophosphatidylserine. The yields of lysophosphatidylserine at the end of each of the four stages outlined above were approximately $100,80,64$ and $41 \%$ respectively on a phosphorus basis.
Further purification of lysophosphatidylserine; crystallization from ethanol. Lysophosphatidylserine was dissolved in hot ethanol to give a concentration of approx. $6 \mathrm{mg}$. of phosphorus $/ \mathrm{ml}$. The insoluble residue was filtered off and the filtrate kept at $-10^{\circ}$. The micro-crystals which formed were circular with radiating striations grouped in the form of a maltese cross showing birefringence under polarized light. The yield was $23 \%$. The sintering point of the crystals was $122^{\circ}$ (corrected) and the m.p. 157-159 (corrected).

Precipitation by acetone. Lysophosphatidylserine was dissolved in chloroform-methanol-water $(86: 14: 1$, by vol.) to give a final concentration of $10 \mathrm{mg}$. of phosphorus/ml. Acetone $\left(4 \mathrm{vol}\right.$.) at $-10^{\circ}$ was then added slowly with shaking. The mixture was kept at $-10^{\circ}$ for $20 \mathrm{~min}$. and the precipitate collected on a Büchner funnel and washed with cold acetone. The yield after precipitation was $85 \%$, and the almost white material gave nearly colourless solutions in chloroform. There was no evidence of crystal structure in the precipitate.

Analytical data on the material obtained by crystallization and precipitation are given in Table 1 , and are in good agreement with the theoretical values for lysophosphatidylserine.

\section{RESULTS AND DISCUSSION}

In initial experiments, when fraction III was chromatographed on silicic acid columns, $80 \%$ of the applied phosphorus was eluted with chloroformmethanol $(4: 1, \mathrm{v} / \mathrm{v})$ [Fig. $1(a)$, first peak]. Small amounts of material were further eluted with chloroform-methanol $(3: 2, \mathrm{v} / \mathrm{v})$ and chloroformmethanol $(1: 4, \mathrm{v} / \mathrm{v})$. The lipid corresponding to the major peak was allowed to react with snake venom in the system described and the reaction products in the chloroform-methanol extract of the reaction mixture were reapplied to an identical column.

Table 1. Analytical data on acid-washed fraction III and lysophosphatidylserine

For experimental details see the text. The molar ratios given are all relative to phosphorus (1.00).

\begin{tabular}{|c|c|c|c|c|c|c|c|c|}
\hline \multirow{3}{*}{$\begin{array}{l}\text { Prepara- } \\
\text { tion }\end{array}$} & \multirow[b]{3}{*}{ Substance } & \multirow[b]{3}{*}{ Remarks } & \multicolumn{4}{|c|}{ Molar ratios } & \multirow{2}{*}{\multicolumn{2}{|c|}{ Phosphorus (\%) }} \\
\hline & & & \multirow{2}{*}{$\begin{array}{l}\text { Fatty } \\
\text { acid }\end{array}$} & \multirow[b]{2}{*}{ Serine } & \multirow{2}{*}{$\begin{array}{l}\text { Ethanol- } \\
\text { amine }\end{array}$} & \multirow{2}{*}{$\begin{array}{l}\text { Acyl } \\
\text { ester }\end{array}$} & & \\
\hline & & & & & & & Found & Calc. \\
\hline \multirow[t]{3}{*}{1} & $\begin{array}{l}\text { Acid-washed } \\
\text { fraction III }\end{array}$ & $\begin{array}{l}\text { Eluted from silicic acid } \\
\text { by chloroform-methanol } \\
(4: 1, v / v)\end{array}$ & 1.98 & 0.88 & 0.05 & $2 \cdot 14$ & $2 \cdot 86$ & $3.92^{*}$ \\
\hline & $\begin{array}{l}\text { Lysophospha- } \\
\text { tidylserine }\end{array}$ & $\begin{array}{l}\text { Eluted from silicic acid } \\
\text { by chloroform-methanol } \\
(3: 2, \mathrm{v} / \mathrm{v})\end{array}$ & 0.95 & 0.92 & 0.02 & 1.09 & $6 \cdot 06$ & $5 \cdot 90 \dagger$ \\
\hline & $\begin{array}{l}\text { Lysophospha- } \\
\text { tidylserine }\end{array}$ & $\begin{array}{l}\text { After further purification } \\
\text { by crystallization from } \\
\text { ethanol }\end{array}$ & $1 \cdot 02$ & 1.04 & 0.00 & - & $6 \cdot 00$ & $5 \cdot 90$ \\
\hline \multirow[t]{3}{*}{2} & $\begin{array}{l}\text { Acid-washed } \\
\text { fraction III }\end{array}$ & $\begin{array}{l}\text { Eluted from silicic acid } \\
\text { by chloroform-methanol } \\
(4: 1, \mathrm{v} / \mathrm{v})\end{array}$ & $2 \cdot 11$ & 0.97 & 0.08 & $2 \cdot 34$ & $2 \cdot 59$ & 3.92 \\
\hline & $\begin{array}{l}\text { Lysophospha- } \\
\text { tidylserine }\end{array}$ & $\begin{array}{l}\text { Eluted from silicic acid } \\
\text { by chloroform-methanol } \\
(3: 2, \mathrm{v} / \mathrm{v})\end{array}$ & $0 \cdot 96$ & 0.92 & 0.00 & 1.08 & $5 \cdot 21$ & $5 \cdot 90$ \\
\hline & $\begin{array}{l}\text { Lysophospha- } \\
\text { tidylserine }\end{array}$ & $\begin{array}{l}\text { After further purification } \\
\text { by precipitation with } \\
\text { acetone }\end{array}$ & $1 \cdot 05$ & 1.02 & 0.00 & - & $5 \cdot 94$ & $5 \cdot 90$ \\
\hline
\end{tabular}


A small amount of material was eluted with chloroform-methanol $(4: 1, \mathrm{v} / \mathrm{v})$ but the bulk of the lipid was subsequently eluted from this second column with chloroform-methanol $(3: 2, \mathrm{v} / \mathrm{v})$. This material was shown to have a fatty acid: phosphorus ratio of 1.00 , a serine:phosphorus ratio of 0.99 , and an ethanolamine:phosphorus ratio of 0.01 ; this suggested that the material was nearly pure lysophosphatidylserine.

Attempts to repeat the procedure were, however, unsuccessful, since different batches of fraction III gave differing elution patterns when chromatographed on silicic acid. Out of four subsequent preparations of fraction III, three gave elution curves similar to that of Fig. $1(b)$, and one gave a curve intermediate between those of Fig. $1(a)$ and Fig. $1(b)$. Analysis of material, present in the three peaks obtained by chromatography of a sample of fraction III giving an elution pattern similar to that of Fig. $1(b)$, showed that phosphatidylserine was the major constituent of material corresponding to the first peak, and that the material corresponding to the second and third peaks was pure phosphatidylserine.

To achieve standard preparations of substrate it was necessary to determine the cause of the variability in the chromatographic behaviour of fraction III on silicic acid columns. Experiments showed that washing fraction III with dilute hydrochloric acid was effective in converting the phosphatidylserine present into a form that was regularly eluted with chloroform-methanol $(4: 1, \mathrm{v} / \mathrm{v})$, the elution curve showing a single sharp peak. Comparison of Fig. $1(b)$ and Fig. $1(c)$ shows the chromatographic behaviour of a typical preparation of fraction III before and after washing with hydrochloric acid. Presumably the washing with hydrochloric acid converts the phosphatidylserine into the free-acid form, which is then eluted from silicic acid with chloroform-methanol $(4: 1, v / v)$, in agreement with the findings of Marinetti, Erbland \& Stotz (1958). This then allows a clear separation of the substrate from the product of the venom reaction (lysophosphatidylserine) which is eluted only from silicic acid by chloroform-methanol (3:2, v/v). Analytical data on substrate and product are given in Table 1.

Kinetic studies on the rate of breakdown of the substrate prepared as described above were outside the scope of the present work, but during the $18 \mathrm{hr}$. of incubation allowed for the reaction in the preparative work, the acyl ester:phosphorus ratio decreased by 0.74 and 0.94 in the two consecutive preparations, indicating that hydrolysis was extensive, especially as the substrate was not pure. An analytically pure semple of phosphatidylserine comprising the material corresponding to the second and third peaks from a column similar to that described in Fig. $1(b)$ and which probably consisted mainly of the sodium salt (L. Rathbone \& E. A. Wilkie, unpublished results) underwent almost complete hydrolysis in 1-2 hr. in the system described.

Fatty acids present in lysophosphatidylserine. Gas chromatography of the methyl esters of the fatty acids prepared from lysophosphatidylserine eluted from silicic acid by chloroform-methanol $(3: 2, \mathrm{v} / \mathrm{v})$ (Table 1) showed that these consisted almost entirely of $\mathrm{C}_{18}$-acids (Table 2 ).

Solubility. Lysophosphatidylserine was insoluble in cold methanol and ethanol, but was largely soluble in both alcohols when hot, although in each

Table 2. Fatty acids present in lysophosphatidylserine

For experimental details see the text.

\begin{tabular}{|c|c|c|}
\hline \multirow[b]{2}{*}{ Fatty acid } & \multicolumn{2}{|c|}{ Percentage composition } \\
\hline & Preparation 1 & Preparation 2 \\
\hline $\begin{array}{l}\text { Stearic acid } \\
\text { Oleic acid } \\
\text { Palmitic acid } \\
\text { Lauric acid } \\
\mathrm{C}_{20^{-}} \text {acids } \\
\text { Linoleic acid } \\
\text { Linolenic acid } \\
\text { Traces of } \mathrm{C}_{14^{-}}, \mathrm{C}_{17^{-}} \text {and } \\
\mathrm{C}_{19^{-}} \text {acids }\end{array}$ & $\begin{array}{c}80 \\
17 \\
0 \cdot 8\end{array}$ & $\begin{array}{c}80 \\
15 \\
0.5\end{array}$ \\
\hline
\end{tabular}

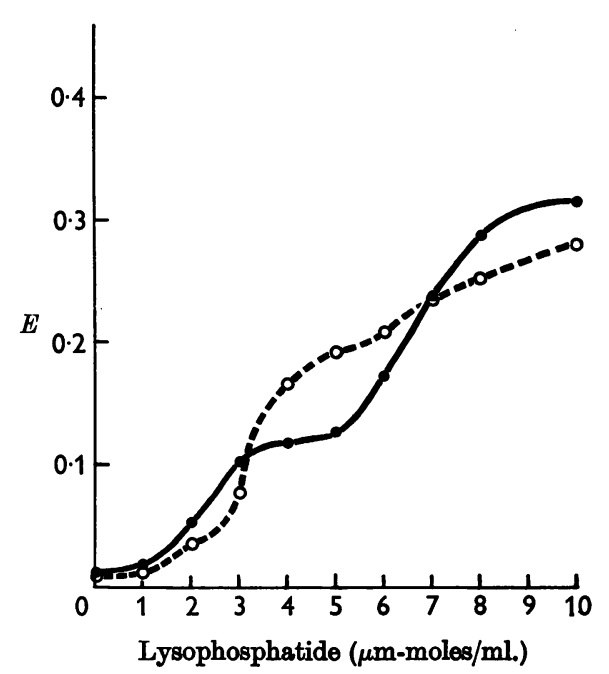

Fig. 2. Haemolytic activities of lysophosphatidylserine and lysolecithin. Washed human-red-blood-cell suspension (1:500) in $0.9 \%$ sodium chloride was incubated at $38^{\circ}$ for $15 \mathrm{~min}$. with amounts of lysophosphatide varying from 0 to $10 \mu \mathrm{m}-\mathrm{moles} / \mathrm{ml}$. At the end of incubation, the mixtures were centrifuged and the extinction of the supernatant was determined in an absorptiometer with an Ilford 604 filter. , Lysolecithin; O, lysophosphatidylserine. 
Table 3. Release of glutamic-oxaloacetic transaminase from rat-brain slices brought about by incubation with lysophosphatidylserine or lysolecithin

\begin{tabular}{|c|c|c|c|}
\hline \multicolumn{4}{|c|}{ For experimental details see the text. } \\
\hline & & \multicolumn{2}{|c|}{$\begin{array}{c}\text { Oxaloacetate formed } \\
(\mu \mathrm{moles} / \mathrm{g} . \text { of tissue } / \mathrm{hr} .)\end{array}$} \\
\hline $\begin{array}{l}\text { Lysophosphatide } \\
\text { present }\end{array}$ & $\begin{array}{c}\text { Incubation } \\
\text { time } \\
\text { (min.) }\end{array}$ & $\begin{array}{l}\text { Enzyme activity } \\
\text { present in } \\
\text { incubation } \\
\text { medium }\end{array}$ & $\begin{array}{c}\text { Increase in } \\
\text { enzyme activity } \\
\text { due to lyso- } \\
\text { phosphatide }\end{array}$ \\
\hline Nil & $\begin{array}{l}20 \\
60\end{array}$ & $\begin{array}{l}262 \\
548\end{array}$ & - \\
\hline Lysophosphatidylserine (3 mM) & $\begin{array}{l}20 \\
60\end{array}$ & $\begin{array}{r}805 \\
1870\end{array}$ & $\begin{array}{r}543 \\
1322\end{array}$ \\
\hline Lysolecithin (3 mM) & $\begin{array}{l}20 \\
60\end{array}$ & $\begin{array}{l}1630 \\
2735\end{array}$ & $\begin{array}{l}1368 \\
2187\end{array}$ \\
\hline
\end{tabular}

case a small amount of insoluble material remained. The lipid formed an emulsion with cold water but dissolved completely in warm water. The substance was insoluble in hot or cold acetone, ether, and light petroleum (b.p. 40-60 $0^{\circ}$.

Biological properties. The haemolytic activity of lysophosphatidylserine eluted from silicic acid (Table 1, preparation 1) was compared with that of crystalline lysolecithin by using a $1: 500$ suspension of washed human red blood cells. Fig. 2 shows that, under the conditions used, these two lysophosphatides have similar haemolytic activities.

The effect of these lysophosphatides in causing cytolysis of nervous tissue was studied by measuring the outflow of the intracellular enzyme glutamic-oxaloacetic transaminase (L-aspartate-2oxoglutarate aminotransferase, EC 2.6.1.1) from rat-brain slices in the presence of the lysophosphatides, according to the technique of McArdle, Thompson \& Webster (1960). Table 3 shows that, under these conditions, the initial rate of release of this transaminase induced by lysophosphatidylserine is about half that caused by an equimolar concentration of lysolecithin.

\section{SUMMARY}

1. Lysophosphatidylserine has been prepared from phosphatidylserine-rich fractions of human brain by reaction with snake-venom phospholipase $A$ in an aqueous system.

2. The successful isolation of the lysophosphatidylserine depended on the differential chromatographic behaviour on silicic acid columns of the acid-washed substrate and of the product of the enzyme reaction.

3. Some of the properties of the purified compound are described.

Our thanks are due to Dr R. W. R. Baker, who kindly carried out the gas-chromatographic analyses, to Miss H. M. Sanders and Miss E. A. Wilkie for their skilled technical assistance, and to the Medical Research Council for their support of this work.

\section{REFERENCES}

Axelrod, J., Reichenthal, J. \& Brodie, B. B. (1953). J. biol. Chem. 204, 903.

Baker, R. W. R. (1961). Biochem. J. 79, 642.

Bartley, W. (1953). Biochem. J. 54, 677.

Berenblum, I. \& Chain, E. (1938). Biochem. J. 32, 295.

Dawson, R. M. C. \& Elliott, W. H. (1959). In Data for Biochemical Research, p. 192. Ed. by Dawson, R. M. C., Elliott, D. C., Elliott, W. H. \& Jones, K. M. Oxford: Clarendon Press.

Folch, J. (1942). J. biol. Chem. 146, 35.

Folch, J., Lees, M. \& Sloane-Stanley, G. H. (1957). J. biol. Chem. 226, 497.

Hanahan, D. J., Dittmer, J. C. \& Warashina, E. (1957). J. biol. Chem. 228, 685.

Long, C. \& Penny, I. F. (1957). Biochem. J. 65, 382.

McArdle, B., Thompson, R. H. S. \& Webster, G. R. (1960). $J$. Neurochem. 5, 135.

Magee, W. L., Baker, R. W. R. \& Thompson, R. H. S. (1960). Biochim. biophys. Acta, 40, 118.

Magee, W. L. \& Thompson, R. H. S. (1960). Biochem. J. 77, 526.

Marinetti, G. V., Erbland, J. \& Stotz, E. (1958). Biochim. biophys. Acta, 30, 41.

Stern, I. \& Shapiro, B. (1953). Brit. J. clin. Path. 6, 158.

Taussky, H. H. \& Shorr, E. (1953). J. biol. Chem. 202, 675. 